\title{
GLUT1 expression in pediatric adrenocortical tumors: a promising candidate to predict clinical behavior
}

\author{
Céline Pinheiro ${ }^{1,2,3,4, *}$, Sara Granja ${ }^{1,2, *}$, Adhemar Longatto-Filho ${ }^{1,2,4,5}$, André $M$. \\ Faria6, Maria C.B.V. Fragoso ${ }^{6,7}$, Silvana M. Lovisolo ${ }^{8}$, Murilo Bonatelli4, Ricardo F.A. \\ Costa $^{3}$, Antonio M. Lerário ${ }^{9}$, Madson Q. Almeida ${ }^{6,7}$, Fátima Baltazar ${ }^{1,2, *}$ and Maria \\ C.N. Zerbini ${ }^{10 *}$ \\ ${ }^{1}$ Life and Health Sciences Research Institute (ICVS), School of Medicine, University of Minho, Braga, Portugal \\ ${ }^{2}$ ICVS/3B's-PT Government Associate Laboratory, Braga/Guimarães, Portugal \\ ${ }^{3}$ Barretos School of Health Sciences Dr. Paulo Prata - FACISB, São Paulo, Brazil \\ ${ }^{4}$ Molecular Oncology Research Center, Barretos Cancer Hospital, São Paulo, Brazil \\ ${ }^{5}$ Laboratory of Medical Investigation (LIM-14), School of Medicina, University of São Paulo, São Paulo, Brazil \\ ${ }^{6}$ Unidade de Suprarrenal, Disciplina de Endocrinologia e Metabologia, Laboratório de Hormônios e Genética Molecular LIM42, \\ Hospital das Clínicas, Faculdade de Medicina da Universidade de São Paulo, São Paulo, Brazil \\ ${ }^{7}$ Instituto do Câncer do Estado de São Paulo - ICESP, Hospital das Clínicas, Faculdade de Medicina da Universidade de São \\ Paulo, São Paulo, Brazil \\ ${ }^{8}$ Hospital Universitário, Faculdade de Medicina da Universidade de São Paulo, São Paulo, Brazil \\ ${ }^{9}$ Department of Internal Medicine, Division of Metabolism, Endocrinology and Diabetes, University of Michigan, Ann Arbor, MI, USA \\ ${ }^{10}$ Departamento de Patologia, Faculdade de Medicina da Universidade de São Paulo, São Paulo, Brazil \\ *These authors have contributed equally to this work \\ Correspondence to: Céline Pinheiro, email: celinepinheiro@gmail.com
}

Keywords: pediatric adrenocortical tumors, metabolic reprogramming, monocarboxylate transporter, glucose transporter, Warburg effect

Received: September 07, $2016 \quad$ Accepted: June 12,2017 Published: July 10, 2017

Copyright: Pinheiro et al. This is an open-access article distributed under the terms of the Creative Commons Attribution License 3.0 (CC BY 3.0), which permits unrestricted use, distribution, and reproduction in any medium, provided the original author and source are credited.

\section{ABSTRACT}

Background: Discrimination between benign and malignant tumors is a challenging process in pediatric adrenocortical tumors. New insights in the metabolic profile of pediatric adrenocortical tumors may contribute to this distinction, predict prognosis, as well as identify new molecular targets for therapy. The aim of this work is to characterize the expression of the metabolism-related proteins MCT1, MCT2, MCT4, CD147, CD44, GLUT1 and CAIX in a series of pediatric adrenocortical tumors.

Methods: A total of $\mathbf{5 0}$ pediatric patients presenting adrenocortical tumors, including 41 clinically benign and 9 clinically malignant tumors, were included. Protein expression was evaluated using immunohistochemistry in samples arranged in tissue microarrays.

Results: The immunohistochemical analysis showed a significant increase in plasma membrane expression of GLUT1 in malignant lesions, when compared to benign lesions $(p=0.004)$, being the expression of this protein associated with shorter overall and disease-free survival $(p=0.004$ and $p=0.001$, respectively). Although significant differences were not observed for proteins other than GLUT1, MCT1, MCT4 and CD147 were highly expressed in pediatric adrenocortical neoplasias (around $\mathbf{9 0 \%}$ ).

Conclusion: GLUT1 expression was differentially expressed in pediatric adrenocortical tumors, with higher expression in clinically malignant tumors, and associated with shorter survival, suggesting a metabolic remodeling towards a hyperglycolytic phenotype in this malignancy. 


\section{INTRODUCTION}

Adrenocortical tumors (ACTs) are common neoplasms with a prevalence higher than $3 \%$ in individuals older than 50 years, being the great majority of these tumors benign [1]. In opposition, adrenocortical carcinoma is a very rare and aggressive event, with an estimated annual worldwide incidence of 0.7-2 new cases per million [2-4]. In children, ACTs are an even more rare event, with an estimated annual worldwide incidence of 0.2-0.3 cases per million children younger than 15 years. Different groups have shown pediatric ACTs are different from adult ACTs [5-7], and, importantly, Weiss' score [8], greatly useful in adults, cannot be applied to children to predict clinical behavior $[6,9,10]$. In fact, children with ACTs apparently with poor prognosis based on adult criteria often have a good clinical outcome $[6,11]$. As a result, in 2003, Wieneke and collaborators, studying a series of 88 pediatric patients ( $<20$ years) with ACTs, proposed a new score for children, based on invasion on vena cava, gross and microscopic features [11]. Although one study validates the reliability of Wieneke's scoring system in predicting malignancy in pediatric ACTs [12], the series was small (only 13 patients) and this system did not gain a great acceptance in the literature yet. Interestingly, Southern Brazil shows an unusually high incidence of pediatric ACTs, with values of 3.4-4.2 per million [2, 4, 13], a fact attributed to the high prevalence of the germline mutation p.R337H in TP53 [14-16]. Currently, complete resection is the best treatment option to achieve cure in this type of cancer [17, 18]; however, long-term survival in children is still limited, with 5-year survival rates greatly varying (virtually from $0 \%$ to $100 \%$ ) as a consequence of different disease presentations [11, 17, 19-21]. Prognostic factors include age, mitotic rate, tumor weight, tumor size, tumor extension, margin status, and presence of metastasis $[19,22,23]$.

The metabolic reprogramming of cancer cells towards aerobic glycolysis, one of the recently defined hallmarks of cancer [24], has gained renewed attention as a potential prognostic and therapeutic tool. As normal epithelial cells become hyperproliferative, they reach the oxygen diffusion limit, leading to a state of intermittent hypoxia. These hypoxic cells can either suffer cell death or suffer a metabolic adaptation to a glycolytic phenotype. In this metabolic reprogramming, also known as the Warburg effect, cancer cells, either in the presence or absence of oxygen, produce energy mainly through glycolysis, whereas pyruvate, instead of being used for oxidative phosphorylation in the mitochondria, is converted to lactate, in a much less energetically efficient process. As a result, cancer cells consume high amounts of glucose to obtain the necessary ATP for proliferation, and produce high amounts of lactate, which is expelled from the cell through specific transporters, contributing to extracellular acidification. To sustain the high glycolytic rates, many metabolism-related proteins are upregulated in cancer, mainly due to the activity of hypoxia inducible factor 1 alpha (HIF-1 $\alpha$ ), the transcription factor involved in cellular responses to hypoxia $[25,26]$. In this context, monocarboxylate transporters (MCTs), responsible for lactate transport, their chaperones CD147 and CD44, as well as the glucose transporter 1 (GLUT1) and the $\mathrm{pH}$ regulator carbonic anhydrase 9 (CAIX) arise as key players in the metabolic reprogramming of cancer cells [27-29].

In a previous study by our group, this metabolic reprogramming was described in adult adrenocortical carcinoma, which was associated with cancer cell aggressiveness [30]. Considering discrimination between benign and malignant tumors is more challenging in pediatric ACTs than in adult tumors [5], new insights in the metabolic profile of pediatric tumors may contribute to this distinction, to predict prognosis as well as to identify new molecular targets for directed therapy. As a result, the aim of the present work is to characterize the expression profile of the metabolism-related proteins MCT1, MCT2, MCT4, CD147, CD44, GLUT1 and CAIX in a series of pediatric ACTs, and its relation with clinical behavior.

\section{RESULTS}

As shown in Figures 1, 2 and 3, the immunohistochemical expression of the metabolism-related proteins in childhood ACTs was found in the cytoplasm, the plasma membrane or both localizations, with a predominance of plasma membrane expression (except for CAIX). All 3 MCT isoforms, as well as the chaperone CD147, were expressed at high frequency in the plasma membrane of most tumor samples (around 60-90\%) and, for MCT4, the frequency of expression was higher in malignant than in benign tumors, however, with no statistical significance. Overall, CD44 was less frequently expressed in tumor samples, being absent from malignant tumors. Regarding the other metabolism-related proteins, GLUT1 and CAIX, a significant increase in the plasma membrane expression of GLUT1 was observed in malignant tumors, compared to benign tumors $(p=0.004)$, but no differences in CAIX expression were observed. Evaluation of co-expression of MCTs with the other proteins at the plasma membrane (Table 1) showed a significant association between MCT4 and both GLUT1 and $\operatorname{CAIX~(~} p=0.002$ and $p=0.036$, respectively).

Taking into account the results obtained for GLUT1, the value of GLUT1 expression as a diagnostic marker was investigated. The positive predictive value of GLUT1 to characterize an adrenal mass as malignant was $41.2 \%$ while the corresponding negative predictive value to rule out malignancy was $93.9 \%$, with a sensitivity of $77.8 \%$, a specificity of $75.6 \%$ and an accuracy of $76.0 \%$. Also, survival analysis showed a significant association of GLUT1 plasma membrane expression with shorter 
overall and disease-free survival ( $p=0.004$ and $p=0.001$, respectively, Figure 4).

\section{DISCUSSION}

In a previous study evaluating the expression and clinical significance of metabolism-related proteins in adult ACTs, MCT4, GLUT1 and CAIX plasma membrane expressions were shown to be significantly increased in carcinomas, when compared to adenomas. Moreover, MCT1, GLUT1 and CAIX plasma membrane expressions in carcinomas were significantly associated with poor prognosis, while MCT2 at the plasma membrane was associated with good prognosis [30]. In fact, although the majority of studies in ACTs using ${ }^{18} \mathrm{~F}$-fluorodeoxyglucose positron emission tomography $\left({ }^{18} \mathrm{~F}-\mathrm{FDG}-\mathrm{PET}\right)$ rely on data obtained mainly or entirely from adult samples, evidence suggest a possible clinical relevance of the glycolytic metabolism, as ${ }^{18} \mathrm{~F}-\mathrm{FDG}-\mathrm{PET}$ may have both a diagnostic and prognostic value in adrenocortical malignancies [31-36]. Specifically in pediatric tumors, one study showed this technique was a satisfactory tool for metastasis screening [37] while another showed avid uptake of ${ }^{18} \mathrm{~F}-\mathrm{FDG}$ by pediatric adrenocortical carcinoma [38]; however, both studies were based only on results from one patient with this type of cancer. Additionally, comparative studies in adult ACTs showed carcinomas, in opposition to adenomas, present biochemical markers

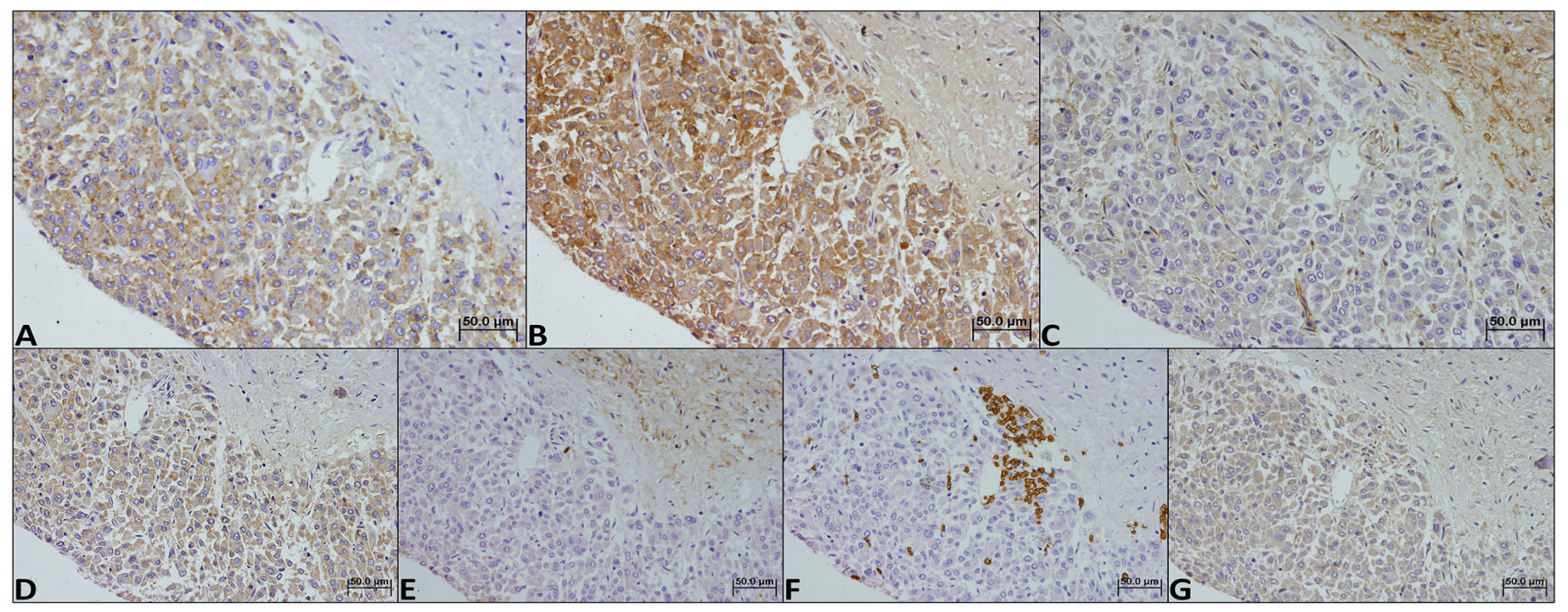

Figure 1: Immunohistochemical expression of MCT1 (A), MCT2 (B), MCT4 (C), CD147 (D), CD44 (E), GLUT1 (F) and CAIX (G) in a benign childhood adrenocortical tumor. Magnification: 400x.

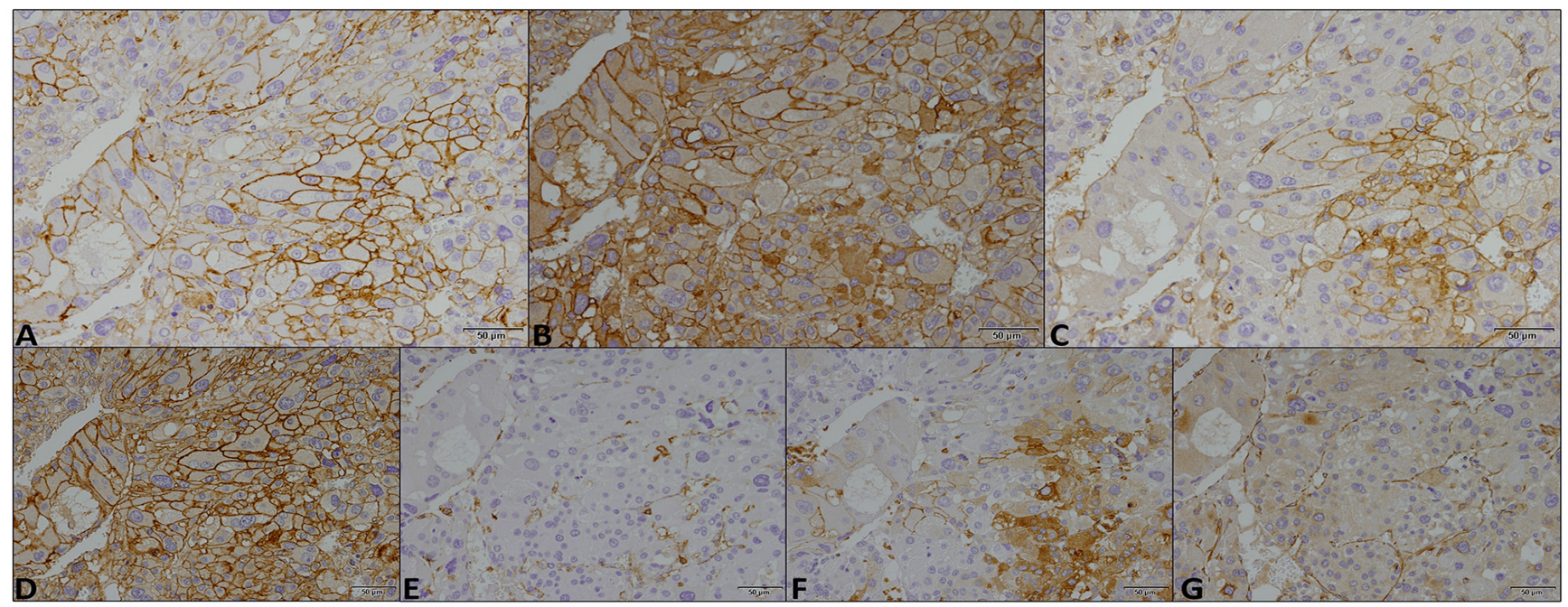

Figure 2: Immunohistochemical expression of MCT1 (A), MCT2 (B), MCT4 (C), CD147 (D), CD44 (E), GLUT1 (F) and CAIX (G) in a malignant childhood adrenocortical tumor. Magnification: 400x. 
Table 1: Co-expression of MCTs with CD147, CD44, GLUT1 and CAIX, in childhood adrenocortical tumor samples (benign and malignant). Only plasma membrane expressions were considered

\begin{tabular}{|c|c|c|c|c|c|c|c|}
\hline & \multirow[t]{2}{*}{$\mathbf{n}$} & \multicolumn{2}{|c|}{ MCT1 } & \multicolumn{2}{|c|}{ MCT2 } & \multicolumn{2}{|c|}{ MCT4 } \\
\hline & & Positive (\%) & $p$ & Positive (\%) & $p$ & Positive (\%) & $p$ \\
\hline CD147 & & & 1.000 & & 0.197 & & 0.118 \\
\hline Negative & 8 & $7(87.5)$ & & $4(50.0)$ & & $3(37.5)$ & \\
\hline Positive & 42 & $35(83.3)$ & & $32(76.2)$ & & $29(69.0)$ & \\
\hline CD44 & & & 1.000 & & 0.278 & & 1.000 \\
\hline Negative & 38 & $32(84.2)$ & & $29(76.3)$ & & $24(63.2)$ & \\
\hline Positive & 12 & $10(83.3)$ & & $7(58.3)$ & & $8(66.7)$ & \\
\hline GLUT1 & & & 1.000 & & 0.511 & & 0.002 \\
\hline Negative & 33 & $28(84.8)$ & & $25(75.8)$ & & 16 (48.5) & \\
\hline Positive & 17 & $14(82.4)$ & & $11(64.7)$ & & $16(94.1)$ & \\
\hline CAIX & & & 0.173 & & 0.140 & & 0.036 \\
\hline Negative & 38 & $30(78.9)$ & & $25(65.8)$ & & $21(55.3)$ & \\
\hline Positive & 12 & $12(100.0)$ & & $11(91.7)$ & & $11(91.7)$ & \\
\hline
\end{tabular}

indicative of increased glycolysis (such as lactate) [39], as well as increased levels of GLUT1 [40] and aldolase A, also a glycolytic enzyme, and decreased levels of proteins related to mitochondrial activity [41], also suggesting a metabolic reprogramming compatible with the Warburg effect. However, no similar studies are available for pediatric ACTs.

Following this line of evidence, in the present study, we characterized the expression of the glycolytic-related proteins: MCT1, MCT2, MCT4, CD147, CD44, GLUT1 and CAIX, in a series of pediatric ACTs. To the best of our knowledge, this is the first study aiming to characterize the metabolic profile of pediatric ACTs.

Herein, in line with the metabolic shift from an oxidative to a glycolytic phenotype, GLUT1 plasmamembrane expression was significantly increased in malignant tissues, compared to benign tissues, similarly to results from adult adrenocortical

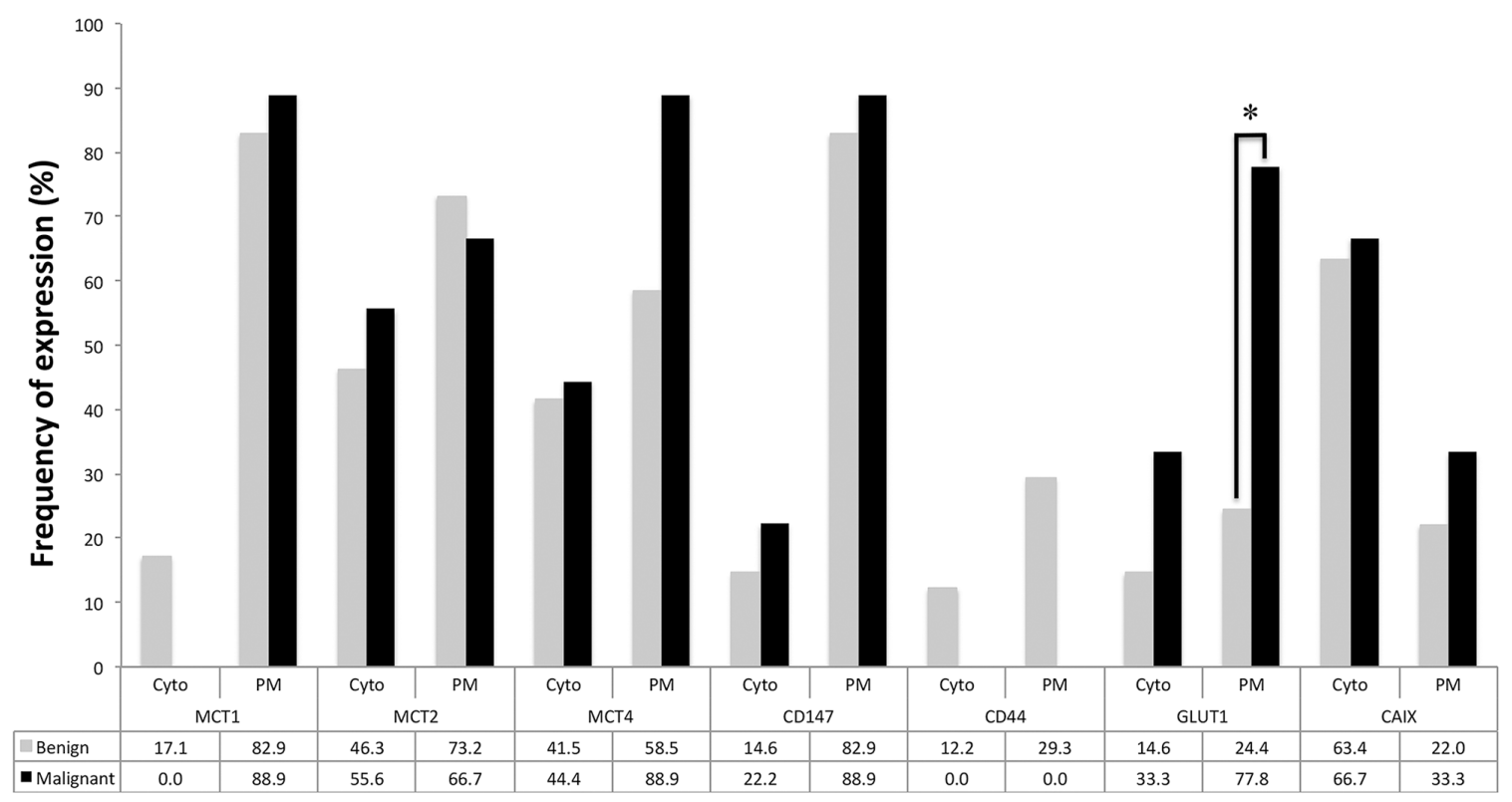

Figure 3: Frequency of expression of the different proteins analyzed in benign and malignant adrenocortical tumors. Pearson's chi-square $\left(\chi^{2}\right)$ test or Fisher's exact test was used to assess differences of expression frequency between benign and malignant tumors. Cyt - cytoplasmic expression; PM - plasma membrane expression; * $p=0.004$. 
Table 2: Clinicopathological data of the pediatric adrenocortical tumor patients

\begin{tabular}{|c|c|c|}
\hline Variable & $\mathbf{n}$ & $\%$ \\
\hline \multicolumn{3}{|l|}{$\operatorname{Age}^{\#}(n=50)$} \\
\hline$\geq 2.2$ years & 28 & 56.0 \\
\hline$<2.2$ years & 22 & 44.0 \\
\hline \multicolumn{3}{|l|}{ Gender $(n=50)$} \\
\hline Female & 30 & 60.0 \\
\hline Male & 20 & 40.0 \\
\hline \multicolumn{3}{|c|}{ TP53 germline mutation status $(n=34)$} \\
\hline Wild type & 8 & 23.5 \\
\hline Mutated & 26 & 76.5 \\
\hline \multicolumn{3}{|c|}{ Tumor size $(\mathbf{n}=\mathbf{5 0})$} \\
\hline$<5 \mathrm{~cm}$ & 20 & 40.0 \\
\hline$\geq 5 \mathrm{~cm}$ & 30 & 60.0 \\
\hline \multicolumn{3}{|c|}{ Tumor weight ${ }^{\#}(n=48)$} \\
\hline$<40.0 \mathrm{mg}$ & 21 & 43.8 \\
\hline$\geq 40.0 \mathrm{mg}$ & 27 & 56.3 \\
\hline \multicolumn{3}{|c|}{ Weiss score $(n=49)$} \\
\hline 1 & 4 & 8.2 \\
\hline 2 & 5 & 10.2 \\
\hline 3 & 5 & 10.2 \\
\hline 4 & 7 & 14.3 \\
\hline 5 & 11 & 22.4 \\
\hline 6 & 9 & 18.4 \\
\hline 7 & 6 & 12.2 \\
\hline 8 & 1 & 2.0 \\
\hline 9 & 1 & 2.0 \\
\hline \multicolumn{3}{|c|}{ Nuclear grade* $(n=18)$} \\
\hline Low & 4 & 22.2 \\
\hline High & 14 & 77.8 \\
\hline \multicolumn{3}{|c|}{ Mitotic index* $(n=18)$} \\
\hline Low & 9 & 50.0 \\
\hline High & 9 & 50.0 \\
\hline \multicolumn{3}{|c|}{ Atypical mitosis $(n=18)$} \\
\hline Absent & 8 & 44.4 \\
\hline Present & 10 & 55.6 \\
\hline \multicolumn{3}{|l|}{ Necrosis $(n=18)$} \\
\hline Absent & 11 & 61.1 \\
\hline \multirow[t]{2}{*}{ Present } & 7 & 38.9 \\
\hline & & \\
\hline
\end{tabular}




\begin{tabular}{lcc}
\hline Variable & $\mathbf{n}$ & \% \\
\hline Venous invasion (n=18) & $\mathbf{1 4}$ & 77.8 \\
Absent & $\mathbf{4}$ & 22.2 \\
Present & & \\
Sinus invasion (n=18) & $\mathbf{1 6}$ & 88.0 \\
Absent & $\mathbf{2}$ & 11.1 \\
Present & & \\
Capsular invasion (n=18) & $\mathbf{1 5}$ & 83.3 \\
Absent & $\mathbf{3}$ & 16.7 \\
Present & & \\
Metastasis (n=50) & $\mathbf{4 1}$ & 82.0 \\
Absent & $\mathbf{9}$ & 18.0 \\
Present & & 52.0 \\
Staging (n=50) & $\mathbf{2 6}$ & 40.0 \\
I & $\mathbf{2 0}$ & 4.0 \\
II & $\mathbf{2}$ & 4.0 \\
III & $\mathbf{2}$ & \\
IV & & \\
\hline
\end{tabular}

\# Median values were used for cut-off as these variables followed a non-normal distribution. * Nuclear grade and mitotic index were defined according to Weiss score definitions [8].

carcinomas [30, 40]. Also, GLUT1 expression was associated with shorter overall and disease-free survival, indicating this protein can contribute to predict malignancy in pediatric ACTs, as, presently, there is no adequate scoring system to predict clinical behavior in this type of tumor [6, 9-11]. In opposition, although expressed at high frequencies at the plasma membrane of neoplastic cells, the $3 \mathrm{MCT}$ isoforms as well as the chaperone CD147 were not significantly differently expressed in benign
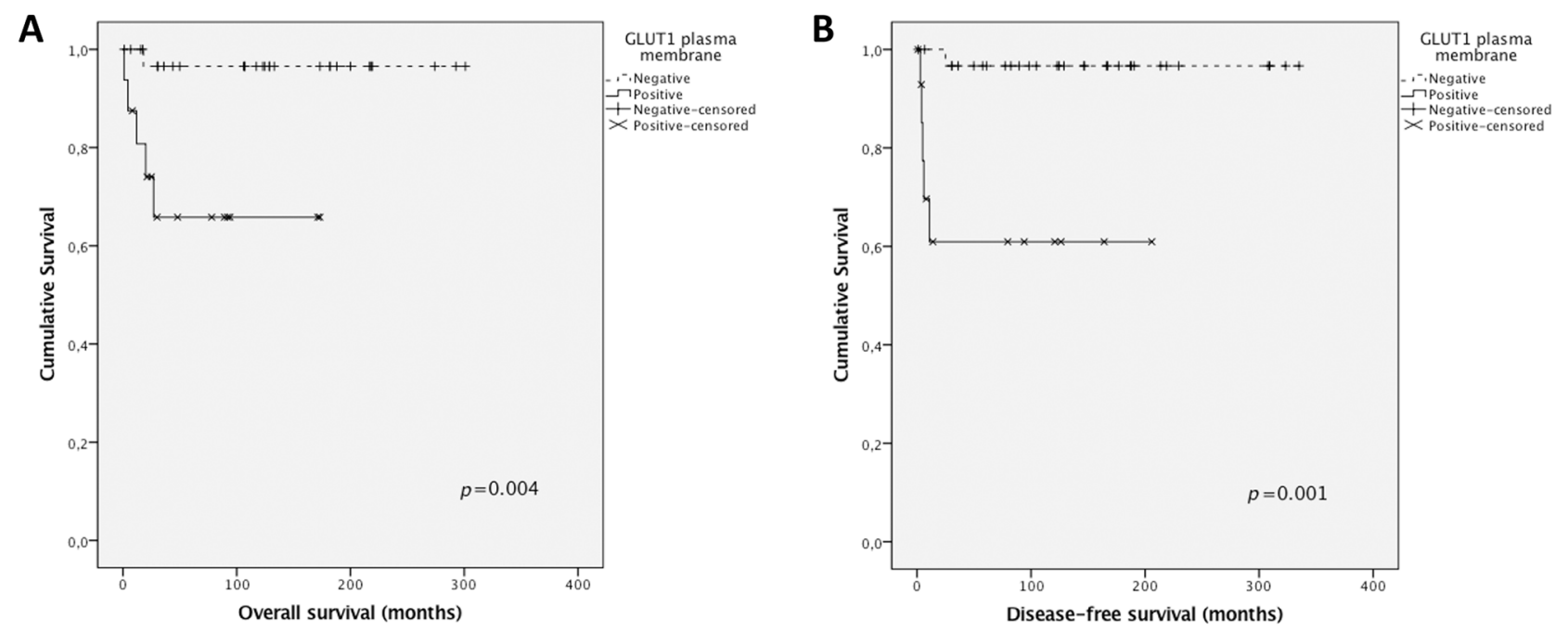

Figure 4: Overall and disease-free survival curves of pediatric adrenocortical carcinomas' patients. The results are stratified according to protein immunohistochemical expression. Only significant results are shown. Continuous line refers to positive expression while interrupted line refers to negative expression. (A) Association of GLUT1 plasma membrane expression with overall survival; (B) Association of GLUT1 plasma membrane expression with disease-free survival. 
Table 3: Detailed aspects for each antibody used in immunohistochemistry

\begin{tabular}{lccc}
\hline Protein & Antigen retrieval & Antibody (product \# and company) & $\begin{array}{c}\text { Antibody dilution and } \\
\text { incubation time }\end{array}$ \\
\hline MCT1 & Citrate buffer $(0.01 \mathrm{M}, \mathrm{pH}=6), 98^{\circ} \mathrm{C}, 20^{\prime}$ & AB3538P Merck-Millipore & $1: 200$, overnight \\
MCT2 & Citrate buffer $(0.01 \mathrm{M}, \mathrm{pH}=6), 98^{\circ} \mathrm{C}, 20$ & sc-50322 Santa Cruz Biotechnology & $1: 200,2$ hours \\
MCT4 & Citrate buffer $(0.01 \mathrm{M}, \mathrm{pH}=6), 98^{\circ} \mathrm{C}, 20^{\prime}$ & sc-50329 Santa Cruz Biotechnology & $1: 500,2$ hours \\
CD147 & EDTA $(1 \mathrm{mM}, \mathrm{pH}=8), 98^{\circ} \mathrm{C}, 20^{\prime}$ & sc-71038 Santa Cruz Biotechnology & $1: 400$, overnight \\
CD44 & Citrate buffer $(0.01 \mathrm{M}, \mathrm{pH}=6), 98^{\circ} \mathrm{C}, 20$ & MCA2726 AbD Serotec & $1: 2000,2$ hours \\
GLUT1 & Citrate buffer $(0.01 \mathrm{M}, \mathrm{pH}=6), 98^{\circ} \mathrm{C}, 20^{\prime}$ & ab15309-500 AbCam & $1: 500,2$ hours \\
CAIX & Citrate buffer $(0.01 \mathrm{M}, \mathrm{pH}=6), 98^{\circ} \mathrm{C}, 20$, & ab15086 AbCam & $1: 2000,2$ hours \\
\hline
\end{tabular}

and malignant samples. In fact, with the exception of MCT4, expression frequencies of these proteins were very similar between groups. To note, the malignant tumor group included only 9 samples, which may explain the lack of significance in MCT4 plasma membrane expression frequencies between groups, as the statistical power was only sufficient to detect high differences in expression frequencies, such as the one found for GLUT1. The lack of CD44 in malignant samples suggests this protein is not a chaperone for MCT1 or MCT4 in malignant ACTs and has no role in pediatric adrenocortical malignancy. Finally, CAIX, a pH regulator upregulated in a variety of cancers, including adult adrenocortical carcinomas [30], showed similar expression between benign and malignant samples, suggesting other $\mathrm{pH}$ regulator, such as CAXII, should be involved in the acid-resistant phenotype associated with the hyperglycolytic phenotype depicted by GLUT1 overexpression. Interestingly, although MCT4 and CAIX were not differently expressed in malignant samples, compared to benign samples, MCT4 was associated with GLUT1 and CAIX, which is coherent with a protein profile remodeling towards a hyperglycolytic and acid-resistant phenotype.

Considering pediatric ACTs and adult ACTs show different genetic backgrounds, such as TP53 mutations, as well as different molecular mechanism involved in tumorigenesis $[5,7]$, and oncogenes and tumor suppressors are important regulators of cancer cell metabolism [42], it is not surprising the expression of metabolism-related proteins in pediatric ACTs found in the present study shows some differences, when compared with a previous study with adult ACTs [30]. However, overall, the findings point at the same direction, which is a metabolic reprogramming towards a glycolytic phenotype in adrenocortical malignant tumors. Previous studies focusing on the biological aspects behind malignancy in pediatric ACTs have identified the insulin-like growth factor (IGF) system, specifically the pair IGF2/IGF1 receptor (IGF1R), as one of the molecular mechanisms involved in the process of tumorigenesis [43-46]. Although some of the signaling proteins downstream of IGF1R, such as Akt, mTOR and AMP-activated protein kinase (AMPK), have a pivotal role in cancer cell metabolic reprogramming $[42,47,48]$, the possible role of IGF1R as a mediator of the Warburg effect has not been clearly established. Nevertheless, the use of a specific antibody targeting IGF1R in neuroblastoma and breast cancer xenograft models showed an antitumor activity, associated with a decrease in glucose uptake [49]. Additionally, IGF1R knockdown inhibited anchorage-independent growth of glioma cells, associated with a decreased glycolytic phenotype [50]. As a result, IGFR1 overexpression in pediatric malignant ACTs may be involved in a metabolic reprogramming towards a hyperglycolytic phenotype.

Targeting the metabolic reprogramming of cancer cells has been pointed out as a potential therapeutic tool and GLUT1 emerges as one of the promising target protein [27, 51, 52]. In fact, promising results on GLUT1 targeting, alone or in combination with conventional treatment, in a variety of tumor models are being described [53-55] and, based on the results from the present study, we anticipate pediatric adrenocortical carcinomas may also benefit from this therapeutic strategy.

Although showing promising results, the present investigation presents limitations, being the most critical the low number of cases available to be tested. Further studies, with more robust series, are warranted to increase statistical power and allow additional findings, including verification of MCT4 overexpression in malignant samples as well as association of the metabolic profile with clinicopathological data. Like in adult adrenocortical tumors, where GLUT1 was described as a stageindependent predictor of clinical outcome [40], the proteins herein analyzed may show clinicopathological significance.

In the present study, GLUT1 expression was differentially expressed in pediatric ACTs, with a higher expression in clinically malignant tumors than clinically benign tumors, and was associated with shorter overall and diseasefree survival, suggesting a metabolic remodeling towards malignancy in these tumors.

\section{MATERIAL AND METHODS}

\section{Human childhood adrenocortical tumor samples}

The tumor series included 50 formalin-fixed paraffin-embedded ACTs (41 clinically benign and 9 clinically malignant lesions), retrieved from the files of the 
Pathology Department of the Clinical Hospital, School of Medicine, University of São Paulo, Brazil. Samples were organized into tissue microarrays (TMA) and each case was represented by three cores (1.0 $\mathrm{mm}$ diameter). Control samples (kidney) were included for TMA orientation. Cases were classified as clinically malignant if metastatic disease was detected. Clinicopathological data for the ACTs included age at diagnosis (non-normal distribution, median 2.2 years, range: 0.5 to 13 years), gender, TP53 status, tumor size (non-normal distribution, median $5.0 \mathrm{~cm}$, range: 1.5 to $21.0 \mathrm{~cm}$ ) and weight (non-normal distribution, median $40.0 \mathrm{mg}$, range: 4.0 to $650.0 \mathrm{mg}$ ), Weiss score and its individual histological parameters [8], staging (according to ENSAT system [56]), metastasis, progression-free survival and overall survival. Detailed information of the clinicopathological data for the childhood ACTs is presented in Table 2. The study was approved by the Local Ethic Committee (number 11090).

\section{Immunohistochemistry}

MCT1 immunohistochemistry was performed according to the avidin-biotin-peroxidase complex method (R.T.U. VECTASTAIN Elite ABC Kit (Universal), Vector Laboratories, Burlingame, CA), as previously described [57]. Immunohistochemistry for MCT2, MCT4, GLUT1, CD44 and CAIX was performed according to the streptavidinbiotin-peroxidase complex method (UltraVision Detection System Anti-polyvalent, HRP, Lab Vision Corporation, Fremont, CA), as previously described [58-60]. CD147 immunostaining was performed using a polymer system (UltraVision ONE Detection System: HRP Polymer Lab Vision Corporation, Fremont, CA) as previously described [61]. Negative controls were performed by the use of appropriate serum controls for the primary antibodies (N1698 and N1699, Dako, Carpinteria, CA). Colon carcinoma tissue was used as positive control for MCT1, MCT4, CD147 and CD44, head and neck squamous cell carcinoma was used for GLUT1, and normal stomach was used for CAIX. Tissue sections were counterstained with hematoxylin and permanently mounted. Detailed aspects for each antibody used are depicted in Table 3.

\section{Immunohistochemical evaluation}

Sections were scored semi-quantitatively for extension of expression in cancer cells as follows: 0: no immunoreactive cells; $1:<5 \%$ of immunoreactive cells; $2: 5-50 \%$ of immunoreactive cells; and 3: $>50 \%$ of immunoreactive cells. Also, intensity of staining was scored semi-qualitatively as follows: 0 : negative; 1 : weak; 2 : intermediate; and 3 : strong. The final score was defined as the sum of both parameters (extension and intensity), and grouped as negative (score 0 and 2) and positive (score 3-6), as previously described [57]. Protein expression in the different cellular localizations (cytoplasm and plasma membrane) was evaluated separately.

\section{Statistical analysis}

Data were stored and analyzed using the IBM SPSS Statistics software (version 23, IBM Company, Armonk, NY). All comparisons were examined for statistical significance using Pearson's chi-square $\left(\chi^{2}\right)$ test or Fisher's exact test (depending on group size). Overall survival was defined as the time from the date of complete tumor resection to death related to adrenocortical cancer or last follow-up. Disease-free survival was defined as the time from the date of complete tumor resection to the first radiological evidence of disease relapse or death. Overall and disease-free survival curves were estimated by the method of Kaplan-Meier and data compared using the logrank test. Due to the low number of malignant lesions $(9 / 50$, $18 \%$ ), no statistical analysis associating the expression of the metabolism-related proteins with the clinicopathological variables was performed. The threshold for significant $p$ values was established as $p<0.05$.

\section{CONFLICTS OF INTEREST}

The authors have nothing to disclose.

\section{FUNDING}

This work was supported by the Fundação de Amparo à Pesquisa do Estado de São Paulo (FAPESP) to Maria Claudia Nogueira Zerbini (2013/26344-8) and under the scope of the project NORTE-01-0145FEDER-000013, supported by the Northern Portugal Regional Operational Programme (NORTE 2020), under the Portugal 2020 Partnership Agreement, through the European Regional Development Fund (FEDER) and by FEDER, through the Competitiveness Factors Operational Programme (COMPETE), and by National funds, through the Foundation for Science and Technology (FCT), under the scope of the project POCI-01-0145-FEDER-007038.

\section{REFERENCES}

1. Grumbach MM, Biller BM, Braunstein GD, Campbell KK, Carney JA, Godley PA, Harris EL, Lee JK, Oertel YC, Posner MC, Schlechte JA, Wieand HS. Management of the clinically inapparent adrenal mass ("incidentaloma"). Ann Intern Med. 2003; 138:424-429.

2. Else T, Kim AC, Sabolch A, Raymond VM, Kandathil A, Caoili EM, Jolly S, Miller BS, Giordano TJ, Hammer GD. Adrenocortical carcinoma. Endocr Rev. 2014; 35:282-326.

3. Fassnacht M, Kroiss M, Allolio B. Update in adrenocortical carcinoma. J Clin Endocrinol Metab. 2013; 98:4551-4564.

4. Fassnacht M, Libe R, Kroiss M, Allolio B. Adrenocortical carcinoma: a clinician's update. Nat Rev Endocrinol. 2011; 7:323-335. 
5. Faria AM, Almeida MQ. Differences in the molecular mechanisms of adrenocortical tumorigenesis between children and adults. Mol Cell Endocrinol. 2012; 351:52-57.

6. Mendonca BB, Lucon AM, Menezes CA, Saldanha LB, Latronico AC, Zerbini C, Madureira G, Domenice S, Albergaria MA, Camargo MH, Madureira G, Domenice S, Pereira MAA, et al. Clinical, hormonal and pathological findings in a comparative study of adrenocortical neoplasms in childhood and adulthood. J Urol. 1995; 154:2004-2009.

7. Lalli E, Figueiredo BC. Pediatric adrenocortical tumors: what they can tell us on adrenal development and comparison with adult adrenal tumors. Front Endocrinol (Lausanne). 2015; 6:23.

8. Weiss LM. Comparative histologic study of 43 metastasizing and nonmetastasizing adrenocortical tumors. Am J Surg Pathol. 1984; 8:163-169.

9. Lucon AM, Pereira MA, Mendonca BB, Zerbini MC, Saldanha LB, Arap S. Adrenocortical tumors: results of treatment and study of Weiss's score as a prognostic factor. Rev Hosp Clin Fac Med Sao Paulo. 2002; 57:251-256.

10. Papotti M, Libe R, Duregon E, Volante M, Bertherat J, Tissier F. The Weiss score and beyond--histopathology for adrenocortical carcinoma. Horm Cancer. 2011; 2:333-340.

11. Wieneke JA, Thompson LD, Heffess CS. Adrenal cortical neoplasms in the pediatric population: a clinicopathologic and immunophenotypic analysis of 83 patients. Am J Surg Pathol. 2003; 27:867-881.

12. Chatterjee G, DasGupta S, Mukherjee G, Sengupta M, Roy P, Arun I, Datta C, Mishra PK, Banerjee S, Chatterjee U. Usefulness of Wieneke criteria in assessing morphologic characteristics of adrenocortical tumors in children. Pediatr Surg Int. 2015; 31:563-571.

13. Custodio G, Komechen H, Figueiredo FR, Fachin ND, Pianovski MA, Figueiredo BC. Molecular epidemiology of adrenocortical tumors in southern Brazil. Mol Cell Endocrinol. 2012; 351:44-51.

14. Ribeiro RC, Sandrini F, Figueiredo B, Zambetti GP, Michalkiewicz E, Lafferty AR, DeLacerda L, Rabin M, Cadwell C, Sampaio G, Cat I, Stratakis CA, Sandrini R. An inherited p53 mutation that contributes in a tissue-specific manner to pediatric adrenal cortical carcinoma. Proc Natl Acad Sci U S A. 2001; 98:9330-9335.

15. Latronico AC, Pinto EM, Domenice S, Fragoso MC, Martin RM, Zerbini MC, Lucon AM, Mendonca BB. An inherited mutation outside the highly conserved DNA-binding domain of the p53 tumor suppressor protein in children and adults with sporadic adrenocortical tumors. J Clin Endocrinol Metab. 2001; 86:4970-4973.

16. Pinto EM, Billerbeck AE, Villares MC, Domenice S, Mendonca BB, Latronico AC. Founder effect for the highly prevalent $\mathrm{R} 337 \mathrm{H}$ mutation of tumor suppressor p53 in Brazilian patients with adrenocortical tumors. Arq Bras Endocrinol Metabol. 2004; 48:647-650.
17. Michalkiewicz E, Sandrini R, Figueiredo B, Miranda EC, Caran E, Oliveira-Filho AG, Marques R, Pianovski MA, Lacerda L, Cristofani LM, Jenkins J, Rodriguez-Galindo C, Ribeiro RC. Clinical and outcome characteristics of children with adrenocortical tumors: a report from the International Pediatric Adrenocortical Tumor Registry. J Clin Oncol. 2004; 22:838-845.

18. Stewart JN, Flageole H, Kavan P. A surgical approach to adrenocortical tumors in children: the mainstay of treatment. J Pediatr Surg. 2004; 39:759-763.

19. McAteer JP, Huaco JA, Gow KW. Predictors of survival in pediatric adrenocortical carcinoma: a Surveillance, Epidemiology, and End Results (SEER) program study. J Pediatr Surg. 2013; 48:1025-1031.

20. Hanna AM, Pham TH, Askegard-Giesmann JR, Grams JM, Iqbal CW, Stavlo P, Moir CR. Outcome of adrenocortical tumors in children. J Pediatr Surg. 2008; 43:843-849.

21. Sandrini R, Ribeiro RC, DeLacerda L. Childhood adrenocortical tumors. J Clin Endocrinol Metab. 1997; 82:2027-2031.

22. Klein JD, Turner CG, Gray FL, Yu DC, Kozakewich HP, Perez-Atayde AR, Voss SD, Zurakowski D, Shamberger RC, Weldon CB. Adrenal cortical tumors in children: factors associated with poor outcome. J Pediatr Surg. 2011; 46:1201-1207.

23. Gulack BC, Rialon KL, Englum BR, Kim J, Talbot LJ, Adibe OO, Rice HE, Tracy ET. Factors associated with survival in pediatric adrenocortical carcinoma: An analysis of the National Cancer Data Base (NCDB). J Pediatr Surg. 2016; 51:172-177.

24. Hanahan D, Weinberg RA. Hallmarks of cancer: the next generation. Cell. 2011; 144:646-674.

25. Gatenby RA, Gillies RJ. Why do cancers have high aerobic glycolysis? Nat Rev Cancer. 2004; 4:891-899.

26. Gillies RJ, Gatenby RA. Metabolism and its sequelae in cancer evolution and therapy. Cancer J. 2015; 21:88-96.

27. Granja S, Pinheiro C, Reis RM, Martinho O, Baltazar F. Glucose addiction in cancer therapy: advances and drawbacks. Curr Drug Metab. 2015; 16:221-242.

28. Baltazar F, Pinheiro C, Morais-Santos F, Azevedo-Silva J, Queiros O, Preto A, Casal M. Monocarboxylate transporters as targets and mediators in cancer therapy response. Histol Histopathol. 2014; 29:1511-1524.

29. Chiche J, Brahimi-Horn MC, Pouyssegur J. Tumour hypoxia induces a metabolic shift causing acidosis: a common feature in cancer. J Cell Mol Med. 2010; 14:771-794.

30. Pinheiro C, Granja S, Longatto-Filho A, Faria AM, Fragoso MC, Lovisolo SM, Lerario AM, Almeida MQ, Baltazar F, Zerbini MC. Metabolic reprogramming: a new relevant pathway in adult adrenocortical tumors. Oncotarget. 2015; 6:44403-44421. doi: 10.18632/oncotarget.5623. 
31. Nunes ML, Rault A, Teynie J, Valli N, Guyot M, Gaye D, Belleannee G, Tabarin A. 18F-FDG PET for the identification of adrenocortical carcinomas among indeterminate adrenal tumors at computed tomography scanning. World J Surg. 2010; 34:1506-1510.

32. Deandreis D, Leboulleux S, Caramella C, Schlumberger M, Baudin E. FDG PET in the management of patients with adrenal masses and adrenocortical carcinoma. Horm Cancer. 2011; 2:354-362.

33. Takeuchi S, Balachandran A, Habra MA, Phan AT, Bassett RL Jr, Macapinlac HA, Chuang HH. Impact of (1)(8)F-FDG $\mathrm{PET} / \mathrm{CT}$ on the management of adrenocortical carcinoma: analysis of 106 patients. Eur J Nucl Med Mol Imaging. 2014; 41:2066-2073.

34. Bourdeau I, MacKenzie-Feder J, Lacroix A. Recent advances in adrenocortical carcinoma in adults. Curr Opin Endocrinol Diabetes Obes. 2013; 20:192-197.

35. Satoh K, Patel D, Dieckmann W, Nilubol N, Kebebew E. Whole Body Metabolic Tumor Volume and Total Lesion Glycolysis Predict Survival in Patients with Adrenocortical Carcinoma. Ann Surg Oncol. 2015; 22 Suppl 3:S714-20.

36. Cistaro A, Niccoli Asabella A, Coppolino P, Quartuccio N, Altini C, Cucinotta M, Alongi P, Balma M, Sanfilippo S, Buschiazzo A, Piccardo A, Fanelli M, Sambuceti G, et al. Diagnostic and prognostic value of $18 \mathrm{~F}-\mathrm{FDG}$ PET/CT in comparison with morphological imaging in primary adrenal gland malignancies - a multicenter experience. Hell J Nucl Med. 2015; 18:97-102.

37. Kreissig R, Amthauer H, Krude H, Steinmueller P, Stroszczynski C, Hosten N, Grueters A, Felix R. The use of FDG-PET and CT for the staging of adrenocortical carcinoma in children. Pediatr Radiol. 2000; 30:306.

38. Murphy JJ, Tawfeeq M, Chang B, Nadel H. Early experience with PET/CT scan in the evaluation of pediatric abdominal neoplasms. J Pediatr Surg. 2008; 43:2186-2192.

39. Imperiale A, Elbayed K, Moussallieh FM, Reix N, Piotto M, Bellocq JP, Goichot B, Bachellier P, Namer IJ. Metabolomic profile of the adrenal gland: from physiology to pathological conditions. Endocr Relat Cancer. 2013; 20:705-716.

40. Fenske W, Volker HU, Adam P, Hahner S, Johanssen S, Wortmann S, Schmidt M, Morcos M, Muller-Hermelink HK, Allolio B, Fassnacht M. Glucose transporter GLUT1 expression is an stage-independent predictor of clinical outcome in adrenocortical carcinoma. Endocr Relat Cancer. 2009; 16:919-928.

41. Kjellin H, Johansson H, Hoog A, Lehtio J, Jakobsson PJ, Kjellman M. Differentially expressed proteins in malignant and benign adrenocortical tumors. PLoS One. 2014; 9:e87951.

42. Nagarajan A, Malvi P, Wajapeyee N. Oncogene-directed alterations in cancer cell metabolism. Trends Cancer. 2016; 2:365-377.

43. Wilkin F, Gagne N, Paquette J, Oligny LL, Deal C. Pediatric adrenocortical tumors: molecular events leading to insulin-like growth factor II gene overexpression. J Clin Endocrinol Metab. 2000; 85:2048-2056.

44. West AN, Neale GA, Pounds S, Figueredo BC, Rodriguez Galindo C, Pianovski MA, Oliveira Filho AG, Malkin D, Lalli E, Ribeiro R, Zambetti GP. Gene expression profiling of childhood adrenocortical tumors. Cancer Res. 2007; 67:600-608.

45. Almeida MQ, Fragoso MC, Lotfi CF, Santos MG, Nishi MY, Costa MH, Lerario AM, Maciel CC, Mattos GE, Jorge AA, Mendonca BB, Latronico AC. Expression of insulinlike growth factor-II and its receptor in pediatric and adult adrenocortical tumors. J Clin Endocrinol Metab. 2008; 93:3524-3531.

46. Lira R, Fedatto PF, Marco Antonio DS, Leal LF, Martinelli Junior CE, De Castro M, Tucci Junior S, Neder L, Ramalho LN, Seidinger AL, Cardinalli I, Mastellaro MJ, Yunes JA, et al. IGF2 and IGF1R in pediatric adrenocortical tumors: roles in metastasis and steroidogenesis. Endocr Relat Cancer. 2015; 23:481-93.

47. Kuhajda FP. AMP-activated protein kinase and human cancer: cancer metabolism revisited. Int J Obes (Lond). 2008; 32:S36-41.

48. Cairns RA, Harris IS, Mak TW. Regulation of cancer cell metabolism. Nat Rev Cancer. 2011; 11:85-95.

49. Shang Y, Mao Y, Batson J, Scales SJ, Phillips G, Lackner MR, Totpal K, Williams S, Yang J, Tang Z, Modrusan Z, Tan C, Liang WC, et al. Antixenograft tumor activity of a humanized anti-insulin-like growth factor-I receptor monoclonal antibody is associated with decreased AKT activation and glucose uptake. Mol Cancer Ther. 2008; 7:2599-2608.

50. Wang B, Sun F, Dong N, Sun Z, Diao Y, Zheng C, Sun J, Yang Y, Jiang D. MicroRNA-7 directly targets insulinlike growth factor 1 receptor to inhibit cellular growth and glucose metabolism in gliomas. Diagn Pathol. 2014; 9:211.

51. Vander Heiden MG. Targeting cancer metabolism: a therapeutic window opens. Nat Rev Drug Discov. 2011; 10:671-684.

52. Tennant DA, Duran RV, Gottlieb E. Targeting metabolic transformation for cancer therapy. Nat Rev Cancer. 2010; 10:267-277.

53. Liu W, Fang Y, Wang XT, Liu J, Dan X, Sun LL. Overcoming 5-Fu resistance of colon cells through inhibition of Glut1 by the specific inhibitor WZB117. Asian Pac J Cancer Prev. 2014; 15:7037-7041.

54. Chan DA, Sutphin PD, Nguyen P, Turcotte S, Lai EW, Banh A, Reynolds GE, Chi JT, Wu J, Solow-Cordero DE, Bonnet M, Flanagan JU, Bouley DM, et al. Targeting GLUT1 and the Warburg effect in renal cell carcinoma by chemical synthetic lethality. Sci Transl Med. 2011; 3:94ra70.

55. Amann T, Hellerbrand C. GLUT1 as a therapeutic target in hepatocellular carcinoma. Expert Opin Ther Targets. 2009; 13:1411-1427. 
56. Fassnacht $\mathrm{M}$, Johanssen $\mathrm{S}$, Quinkler $\mathrm{M}$, Bucsky $\mathrm{P}$, Willenberg HS, Beuschlein F, Terzolo M, Mueller HH, Hahner S, Allolio B, German Adrenocortical Carcinoma Registry G, European Network for the Study of Adrenal T. Limited prognostic value of the 2004 International Union Against Cancer staging classification for adrenocortical carcinoma: proposal for a Revised TNM Classification. Cancer. 2009; 115:243-250.

57. Pinheiro C, Longatto-Filho A, Scapulatempo C, Ferreira L, Martins S, Pellerin L, Rodrigues M, Alves VA, Schmitt F, Baltazar F. Increased expression of monocarboxylate transporters 1, 2, and 4 in colorectal carcinomas. Virchows Arch. 2008; 452:139-146.

58. Pinheiro C, Sousa B, Albergaria A, Paredes J, Dufloth R, Vieira D, Schmitt F, Baltazar F. GLUT1 and CAIX expression profiles in breast cancer correlate with adverse prognostic factors and MCT1 overexpression. Histol Histopathol. 2011; 26:1279-1286.
59. Queiros O, Preto A, Pacheco A, Pinheiro C, Azevedo-Silva J, Moreira R, Pedro M, Ko YH, Pedersen PL, Baltazar F, Casal M. Butyrate activates the monocarboxylate transporter MCT4 expression in breast cancer cells and enhances the antitumor activity of 3-bromopyruvate. J Bioenerg Biomembr. 2012; 44:141-153.

60. Pinheiro C, Reis RM, Ricardo S, Longatto-Filho A, Schmitt F, Baltazar F. Expression of monocarboxylate transporters 1,2 , and 4 in human tumours and their association with CD147 and CD44. J Biomed Biotechnol. 2010; 2010:427694.

61. Granja S, Morais-Santos F, Miranda-Goncalves V, VianaFerreira M, Nogueira R, Nogueira-Silva C, Correia-Pinto J, Baltazar F. The monocarboxylate transporter inhibitor alpha-cyano-4-hydroxycinnamic acid disrupts rat lung branching. Cell Physiol Biochem. 2013; 32:1845-1856. 